\title{
FORENSIC MENTAL HEALTH IN EUROPE: SHARED LEGAL HERITAGE AND CONTEMPORARY LANDSCAPE
}

\author{
Jack Tomlin ${ }^{1}$, Birgit Völlm ${ }^{2}$ \\ ${ }^{I}$ School of Law and Criminology Faculty of Liberal Arts and Sciences University of Greenwich, \\ London, UK, \\ ${ }^{2}$ Department for Forensic Psychiatry, University Medical Center, Rostock, Germany
}

Keywords: Europe, forensic mental health, healthcare system, legal framework.

\begin{abstract}
Summary
This paper provides an overview of some of the key features of forensic mental health systems around Europe. Forensic mental health systems share in common the aim to assist in the rehabilitation of people diagnosed with a mental disorder and reduce reoffending or risk of harm. How these aims are pursued varies across the continent. We suggest that best practices can be learnt from observing different countries' approaches. This paper has six foci: legal traditions in Europe, the concept of criminal responsibility, patient pathways through forensic systems, epidemiological studies of forensic patients, training programmes in forensic mental health, and recent developments in the field across Europe. Readers should reflect on these topics in the context of their own country and how these diverge/converge from the countries described in this paper.
\end{abstract}

\section{Introduction}

Forensic mental health is a specialty of medicine. Clinical work should be evidence-based and draw on a wide range of experiences and sources. The growth of the European Union and increased interconnectedness of states in a globalised world encourages the sharing and co-development of best practices in forensic mental health care. Much can be learned from remaining alert to the systems, approaches and future directions of praxis in other countries.

This paper aims to introduce the reader to the similarities and divergences that exist between European forensic mental health systems. First, the background to contemporary civil and common law legal systems is described. Second, criminal responsibility - a core concept in forensic treatment - across different European states is addressed. Third, foren- sic systems, care settings and patient pathways are compared. Fourth, the findings from epidemiological studies are highlighted. Fifth, training programmes in forensic psychiatry in several countries are described. Finally, recent developments in European forensic mental health are discussed.

\section{Research results}

Legal context: The development of common and civil law traditions. Defining laws on criminal responsibility is a matter for individual states. However, many European legal systems share a common legal heritage that can be traced back to Greek and Roman influences. For example, Plato (427-347 BC) recognised the principle that individuals with mental illness should be treated differently following the commission of a harmful act:

'Someone may commit an act when mad or afflicted with disease ... [and if so,] let him pay simply for the damage; and let him be exempt from other punishment. (Plato, 1868 quoted in: van der Wolf \& van Marle, 2018)

Similar attitudes towards mentally disordered offenders can be found in Roman law. Roman laws (ius commune) codified between $100 \mathrm{BC}$ and $300 \mathrm{AD}$ were collated into the Codex Justinianus (part of the Corpus Juris Civilis) around 530 AD [3]. This collection of laws made reference to criminal responsibility, stipulating that a 'lunatic' could not be punished for a criminal act as he/she was 'excused by the misfortune of his fate' [1].

The Codex was used by legal scholars throughout the Middle Ages across much of continental Europe where local legal practices (ius proprium) did not provide adequate guidance on how to settle legal disputes [3]. Modern legal codes in use today such as the French Code pénal (1810) can be placed within these developments [3]. Countries in Europe whose legal heritage can be traced in this way belong to the 'civil law' tradition. This includes most European states, but also Japan and most of South America. Substantive and 
procedural criminal laws are enshrined in legal codes, judges apply these to individual cases. Courts are bound to apply the law; the principle of stare decisis - that lower courts should apply precedents set by higher courts - does not bind civil law courts (with some exceptions, such as rulings from constitutional courts).

Criminal procedure in these countries is inquisitorial. The examining judge plays the role of investigator, questioning witnesses, prosecutors and defence lawyers, and reviewing evidence. This means that the judiciary plays a pivotal and driving role in the progression of a case. Lawyers for a defendant support their client through the proceedings, present the facts of the case from their client's perspective and aim to encourage judges to exercise any discretion they may have in sentencing in favour of their client. The amount of discretion a judge has varies, with Mediterranean countries allowing for more flexibility in rulings, and jurisdictions like France, Belgium and the Netherlands prescribing more detailed laws [1].

England's legal system charted a different course from most of its European counterparts. The main point of divergence lies in the role of the judge. In 1166, King Henry II established a system of travelling justices to enforce his law and appoint local groups of 'jurors' to review cases and decide whether these warranted further adjudication in the courts. These groups developed later into trial juries. Barristers (lawyers qualified to argue in court) started to defend suspects in court in the 1730s [5].

These developments have led to what is known today as the 'common law' tradition. Common law legal systems have been adopted across the globe, including many countries once colonised by the British (e.g. Australia, Canada, New Zealand and the United States). Although much substantive and procedural criminal law has been codified in statute, many features are defined in caselaw or were derived from caselaw. Common law systems, unlike civil law systems, follow the principle of stare decisis, meaning that decisions of higher courts are binding on lower courts. Instead of starting with legal principles and applicable legal provisions as would occur in a civil law jurisdiction, common law lawyers and judges begin with the case or legal issues and then look for past rulings.

Criminal procedure in common law systems is adversarial. Judges are more passive than their civil law counterparts and hear cases presented by lawyers representing the defendant and lawyers representing the state. In England and Wales for example, this is reflected in the naming of cases: $\mathrm{R} v$ Jones or Reg $\mathrm{v}$ Matthews (the ' $\mathrm{R}$ ' indicating 'Regina' (Queen) or 'Rex' (King)). A decision is made by the public prosecutor to charge someone with an offence where there is a public interest to do so. Defendants can hire their own legal services or be assigned this by the state. Thereafter follows proceedings in which both the defence and prosecution pursue their own investigative work and evidence gathering. Herein lies the adversarial aspect of such systems; both the defence and prosecution are competing to persuade a judge or jury of the merits of their arguments. Where trials involving serious offences, the role of the judge is to explain to the jury what their role is and clarify aspects of the proceedings. In England and Wales, it is for the jury to decide on the issues of guilt and the insanity defence [6].

Criminal responsibility. Criminal responsibility is assessed differently in civil and common law jurisdictions. In England \& Wales, the M'Naghten test is used to conclude criminal responsibility: an offender will not be culpable 'if he was labouring under such a defect of reason from disease of the mind, as not to know the nature and quality of the act he was doing; or, if he did know it, that he did not know he was doing what was wrong' (R v M'Naghten (1843) 8 E.R. 718; (1843) 10 Cl. \& F. 200). This test originates in caselaw and additional components, such as the 'irresistible impulse test', have been added to this in subsequent cases [1,7].

The Law Commission for England and Wales reports that in Crown Courts, the insanity defence is used approximately 30 times a year (no data are available for the lower Magistrates' Court) [8]. The insanity defence applies to all criminal defences where there are objective (actus reas) and subjective (mens rea) elements. The requirement that a 'defect of reason from disease of the mind' resulted in the inability to know the nature, quality or wrongfulness of an act means that the approach to criminal responsibility in England and Wales is primarily cognitive. ${ }^{1}$

In many civil law jurisdictions, tests of criminal responsibility are enshrined in statute. These typically have cognitive and volitional elements [1]. An example of this can be seen in $\S 20$ of the German Criminal Code (StGB), which states:

'Whoever, at the time of the commission of the offence, is incapable of appreciating the unlawfulness of their actions

${ }^{1}$ Following a 'special verdict' in a Crown Court, the court can use $\S 5$ Criminal Procedure (Insanity) Act 1964 to order a hospital order as stipulated in $\S 37$ Mental Health Act 1983. Magistrates' Courts can also make use of the hospital order where a defendant was acquitted on the grounds of insanity. Importantly, the hospital order is only used where defendants have a mental disorder at the time of sentencing of such a nature and degree that placement in a psychiatric hospital is warranted. It has no direct link to one's mental state at the time of the offence. Accordingly, defen-dants who have been found fully criminally responsible for an offence but have a mental disorder when this finding is made by a court can receive a hospital order - in fact, most patients ordered forensic treatment have been found guilty of their offence and then subsequently received a hospital order. 


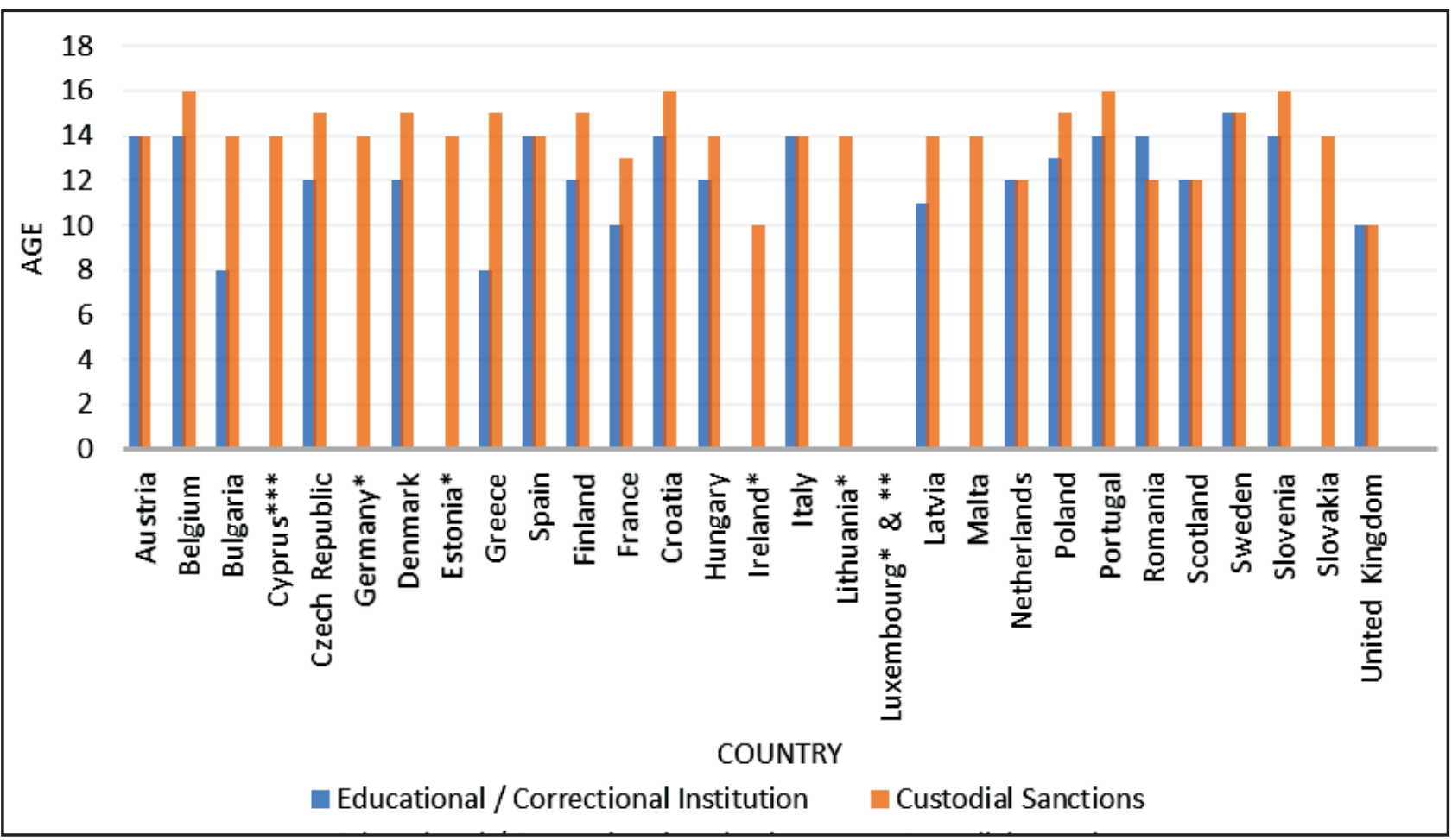

Figure 1. Minimum Age of Educational / Correctional and Custodial Sentences across Europe

Notes: * No minimum age for educational / correctional institutions; ** No minimum age for custodial sanctions; *** No data available for educational / correctional institutions. Data from 2017 collected by the European Union Agency for Fundamental Rights; 'United Kingdom' excludes Scotland.

or of acting in accordance with any such appreciation due to a pathological mental disorder, a profound disturbance of consciousness, mental deficiency or any other serious mental abnormality is deemed to act without guilt.' (bold and underline added for emphasis by the authors).

Several jurisdictions allow for degrees of responsibility. For example, Germany provides for full, absent, and diminished responsibility ( $\$ 21 \mathrm{StGB}$ ), and the Netherlands has a system with five levels [9]. These have consequences on for whom and by which mechanism forensic dispositions can be ordered by a court. The Dutch forensic mental health system has a high number of patients with personality disorders, in part due to its sliding scale approach to responsibility and the assumption that personality disorders do not fully remove one's cognitive or volitional ability to avoid committing a crime but still affect this to some degree.

Despite some similarities in how civil law countries approach criminal responsibility, there are still intriguing differences. For example, Belgium's criminal responsibility provision includes only a volitional criterion [1]. Also of note is that Sweden has no insanity finding at all. In cases involving mentally disordered offenders, defendants will be found guilty and given a forensic treatment order. Juris- diction will pass from the criminal courts to administrative courts, with the treating hospital usually making the decision to discharge the patient [10].

Another key aspect of responsibility is the minimum age of criminal responsibility. So far, this paper has assumed defendants are adults. However, it is important to consider the variety of minimum age thresholds as individuals under the age of 18 can also be subject to criminal sanctions and forensic treatment disposals. Here we compare: 1) the minimum 'age at which children can be placed in ducational or correctional institutions where restrictions of liberty-movement apply'2, and 2) the minimum 'age at which juvenile offenders can be subject to custodial sanctions and measures (detention) ${ }^{3}$ across Europe. These data were collected and updated in 2017 by the European Union Agency for Fun-

2 'When children infringe the law, placing them in special educational institutions, where restrictions of liberty or movement apply, constitutes an alternative to strict detention' (Taken from the European Union Agency for Fundamental Rights, 2018).

3 'Custodial sanctions and measures (detention) for children who infringed criminal law should always be the last resort. Member States define the minimum age thresholds for children to be subject to detention' (Taken from the European Union Agency for Fundamental Rights, 2018). 
damental Rights [11]. These data are presented in Figure 1.

Diagnoses, pathways and care settings. There are common threads traceable through most European forensic systems. Of the 15 countries investigated by Salize and Dreßing (2005), all offered patients the opportunity to appeal their treatment orders; no country systematically violated patients' human rights; treatment was organised across inpatient, outpatient, and prison settings; and very few states enshrined criteria for discharge in the law.

Legal definitions of mental illness/disorder adopted in European countries vary and typically do not reflect clinical diagnoses (e.g. DSM or ICD). This leads to differences in who can be ordered into forensic treatment settings. States are generally in agreement that both in law and practice, patients with organic mental disorders, schizophrenia and other psychotic disorders, and affective (mood) disorders, are eligible for forensic treatment [7]. Greater disparities pertain to personality disorders, paraphilias, and substance use disorders.

The interplay between rehabilitative and punitive sanctions in different states is apparent in forensic patients' treatment pathways. Half of the states in Salize and Dreßing (2005) regulated the sequencing of prison and forensic placements, the others adopted case-by-case assessment. In Belgium, the Netherlands, and France a prison sentence may be served before treatment in a forensic setting. It is possible to serve a prison sentence and forensic treatment concurrently in Luxembourg, Portugal, Spain, Ireland, Greece and Austria. In Germany, Italy and Portugal, it is possible to first receive forensic treatment and then serve a prison sentence. In England \& Wales, a convicted prison inmate who develops symptoms of a mental disorder, or whose pre-existing condition worsens, can be transferred to forensic care and then returned to prison ( $\$ 47$ Mental Health Act 1983).

Treatment is offered across a range of settings including the community, secure forensic hospitals, specialised wards in general psychiatric hospitals, and prisons. Czechia (formerly Czech Republic) is illustrative of this. Protective treatment (PT) orders can be ordered for psychiatric, sex offender, substance abuse, and pathological gambling treatment in general psychiatric hospitals or the community [13]. About 600 patients are ordered into inpatient care and 350 to outpatient care every year. Secure detention (SD) orders are more restrictive measures for patients who pose a significant risk to themselves or others. These are undertaken in one of two high security hospitals. In January 2019, there were 85 such patients [13].

All places where involuntary detention occurs - which includes forensic and general psychiatric hospitals and pri- sons - in the 47 member states of the Council of Europe are obliged to adhere to the European Convention for the Prevention of Torture and Inhuman or Degrading Treatment or Punishment (1953), and caselaw of the European Court of Human Rights (ECtHR), and provide care according to standards articulated by the Committee for the Prevention of Torture (CPT) $[14,15]$. This involves submitting to scheduled and ad-hoc inspections from the CPT and responding proactively to their recommendations $[16,17]$. These institutions should "[...] provide each such person, taking into account his or her state of health and the need to protect the safety of others, with an environment and living conditions as close as possible to those of persons of similar age, gender and culture in the community" (Council of Europe, Recommendation REC(2004)10: art. 9). This statement is demonstrative of a drive to normalise mental health care and provide it in settings close to one's community.

Epidemiological studies and trends. Studies have investigated the epidemiological characteristics of different European forensic systems. Of note is that despite some shared characteristics, there also exists wide variation across systems. Tomlin and colleagues (2021) collected data from 17 European countries in 2013. They found that there was a 17 -fold difference between the rates of forensic inpatients for every 100,000 members of the population. The Netherlands reported 23.9 inpatients per 100,000. In Spain, this number was 1.4. To give a few more examples of inpatients rates: Belgium (17.5), England \& Wales (11.7), Macedonia (7.9), and Portugal (2.4).

Similar variation was observed in relation to mean length of stay in inpatient care and sex. Here, the Netherlands had the longest mean period of treatment at 10 years. Slovenia reported a mean length of stay at 1.04 years. Between these we have: Germany ( 7.95 years), Ireland ( 7.06 years), Italy (2.9 years), and Poland (2.04 years). Men were the clear majority of patients receiving care across all countries. However, England \& Wales (18\%) had over three times the number of women patients than Slovenia (5\%). Latvia reported women constituted $13 \%$, Scotland $9 \%$, and Croatia $6 \%$ of their forensic inpatient populations. For a full breakdown of these data please see Tomlin et al. (2021).

The number of forensic beds has been increasing in most European countries. Chow and Priebe (2016) investigated forensic bed numbers for eleven countries between 1990 and 2012. There were clear increases in the rates per 100,000 for all countries except Italy. Concurrently, most countries saw decreases in the number of general psychiatric beds and a rise in the prison population (Germany being a notable exception to these trends). A decrease in the number of psychiatric 
beds and increase in the prison population is sometimes explained by the Penrose Hypothesis - that the greater the number of people treated in psychiatric settings, the lower the need to detain people in prison and vice versa. However, this has received mixed empirical support [19]. More promising explanations for the patterns in (forensic) bed and prison rates are discernible in a constellation of social and political phenomena: economic prosperity, amount invested in healthcare, social attitudes towards the rehabilitation of offenders, social welfare programmes and so on [19-23].

Training and teaching. Forensic mental health in Europe is an interdisciplinary undertaking. A wide range of tasks are performed by individuals from psychiatry, psychology, legal, nursing, occupational therapy, social work, security, management and administrative backgrounds. Training in these disciplines is not harmonised across Europe, despite efforts towards cross-border recognition of specialisations and continued professional educational events. For example, a discussion of forensic mental health education programmes only identified the U.K., Germany and the Netherlands as having postgraduate degrees in forensic psychology [24].

It is helpful to look at forensic psychiatric training as an example. The U.K. requires individuals to undertake a 4-6year undergraduate medical degree (MBBS, MBChB). This is followed by a two-year Foundation Programme across several medical specialties, and then three years of core training across subspecialties of psychiatry and an exam. Finally, three years of specialist training in forensic psychiatry is needed before a Certificate of Completion of Training (CCT) in Forensic Psychiatry is awarded [25].

In Germany in the 1980s, five institutions independently started offering training in forensic psychiatry [26]. At this time, each had a unique training approach that was influenced by that institution's psychiatric treatment philosophy. The first effort at a national interdisciplinary training course followed before the year 2000 in which the German Association for Psychiatry, Psychotherapy and Psychosomatics (DGPPN) established an initiative to grant certification in forensic psychiatry following completion of a structured training programme [27]. This training requires graduates of medicine undertake 240 hours of theoretical training on a wide range of topics such as criminal responsibility, prison psychiatry, and civil law; 70 psychiatric reports of which 50 must relate to questions of criminal law; and one year of supervised clinical training at a forensic-psychiatric facility authorised to provide higher education or 1600 hours of practical work in a forensic-psychiatric facility without this authorisation, of which 800 hours must related directly to the treatment of mentally disordered offenders [28]. Since 2016, certification is valid for five years and then must be renewed.

\section{Current developments in European forensic mental health}

Two important developments in European forensic mental health are worth noting. Both pivot around the normalisation and empowerment of individuals with mental health disorders. The first concerns the closure of high security hospitals in Italy, the second the growing prevalence of peer support workers.

In Italy, the passage of Law 833/1978 led to the closure of psychiatric 'asylums' [29]. It was not until 2015 that this started to have effect in forensic services. Laws passed in 2008 and 2014 sped up the closure of the remaining forensic high security hospitals (Ospedali Psichiatrici Giudiziari, OPG) and the development of a series of 30 Residences for the Execution of Security Measures (REMs). These are small, community-based residential units with no more than 20 beds and a focus on a recovery model of rehabilitation. This has been seen by many as a triumph for deinstitutionalisation and rehabilitative - as opposed to punitive - approaches to the management of forensic patients. However, as of 2019 there were approximately 604 REM beds compared to 1639 OPG patients in 2008 [30]. This has led to a bottleneck and long waiting lists. Some commentators have highlighted a lack of clear and consistent treatment approaches nationally, and raised the need for specialised treatments and pathways for specific patient groups [30]. Studies are investigating the effectiveness of the REMs [31], the results of which are being watched around Europe.

Another important development in Europe (and elsewhere) is the introduction of peer support workers. Peer support work (PSW) involves "a system of giving and receiving help founded on key principles of respect, shared responsibility, and mutual agreement of what is helpful" [32] (p. 135). Peer support workers aim to offer current patients companionship, empathy, and empowerment to demonstrate how something can occur but people can still move on from these events. There are some barriers to implementing PSW in forensic settings such as security restrictions, punitive or skeptical attitudes from staff, or a lack of resources. A recent survey of all 75 forensic hospitals in Germany found that five reported past or current experience with PSW, with five planning to implement this approach in the future [34]. PSW is much more widespread in general mental health, with many services in countries like the U.K. actively employing part-and full-time PSW staff. An increasing number of peer support workers in forensic settings are likely to be employed across the continent in the coming years.

\section{Conclusion}

European forensic systems share a similar legal heri- 
tage. They are also bound by the same international human rights instruments that demand respect for fundamental freedoms and rights. Several professional organisations exist to share research and best practices in forensic mental health across borders. Systems differ in several key respects and the experiences of mentally disordered offenders can look quite different across European jurisdictions. This paper has outlined some of these differences and highlighted a couple of recent developments. European (and international) forensic mental health patients and staff will benefit from efforts to share research findings and clinical experience. Cross-border collaboration is encouraged to promote the highest standard of evidence-based practice.

\section{References}

1. van der Wolf M, van Marle H. Legal Approaches to Criminal Responsibility of Mentally Disordered Offenders in Europe. in Forensic Psychiatry and Psychology in Europe 31-44 (Springer International Publishing, 2018).

https://doi.org/10.1007/978-3-319-74664-7_3

2. Plato. The Laws. Volume 5. Translation by George Burges. (Dell and Daldy, 1868).

3. Lesaffer R. European legal history: A cultural and political perspective [Translated by Jan Arriens]. European Legal History: A Cultural and Political Perspective (Cambridge University Press, 2009). https://doi.org/10.1017/9781107300866

4. Pejovic C. Civil Law and Common Law: Two Different Paths Leading to the Same Goal. Victoria University of Wellington Law Review 2001;32:817-842. https://doi.org/10.26686/vuwlr.v32i3.5873

5. Gunn J, Mevis P. Adversarial Versus Inquisitorial Systems of Trial and Investigation in Criminal Procedure. in Forensic Psychiatry and Psychology in Europe 3-17. Springer International Publishing 2018. https://doi.org/10.1007/978-3-319-74664-7_1

6. Judicial College. The Crown Court Compendium. Part I: Jury and Trial Management and Summing Up. 2020.

7. Salize H, Dreßing H. Placement and treatment of mentally ill offenders-legislation and practice in EU Member States. 2005.

http://www.krim.dk/undersider/straffuldbyrdelse/forvaring/psykisk-afvigende-indsatte-placering-europa-eu2006.pdf .

8. Law Commission. Criminal Liability: Insanity and Automatism. A Discussion Paper 2013.

9. Edworthy R, Sampson S, Völlm B. Inpatient forensic-psychiatric care: Legal frameworks and service provision in three European countries. International Journal of Law and Psychiatry 2016;47: 18-27.

https://doi.org/10.1016/j.ijlp.2016.02.027

10. Jehle JM, et al. Dealing with Dangerous Offenders in Europe. A Comparative Study of Provisions in England and Wales,
Germany, the Netherlands, Poland and Sweden. Criminal Law Forum 2021;32:181-245.

https://doi.org/10.1007/s10609-020-09411-z

11. European Union Agency for Fundamental Rights. Children and detention | Year: 2017. https://fra.europa.eu/en/publicationsand-resources/data-and-maps/minag (2018).

12. Hillier B, Lambourne C, Taylor P. Mapping Offender-Patient Pathways. in Forensic Psychiatry and Psychology in Europe. Springer International Publishing 2018:91-112 https://doi.org/10.1007/978-3-319-74664-7_6

13. Páv M, et al. Forensic Treatment Services in the Czech Republic: Current State and Future Challenges. International Journal of Forensic Mental Health 2020;19: 269-282. https://doi.org/10.1080/14999013.2020.1732505

14. Council of Europe. European Committee for the Prevention of Torture and Inhuman or Degrading Treatment or Punishment (CPT) CPT/Inf(98)12-part. https://rm.coe.int/16806cd43e (1998).

15. Lehtmets A, Hauksson P. European Committee for the Prevention of Torture and Inhuman or Degrading Treatment or Punishment (CPT) Checklist for the evaluation of a psychiatric hospital. 2009.

16. ECPT. Report to the Government of UK on the visit to the UK carried out by the European Committee for the Prevention of Torture and Inhuman or Degrading Treatment or Punishment. 2014.

17. Council of Europe. Report to the Polish Government on the visit to Poland carried out by the European Committee for the Prevention of Torture and Inhuman or Degrading Treatment or Punishment (CPT) from 11 to 22 May 2017. CPT/Inf 2018;39.

18. Tomlin J, et al. Forensic mental health in Europe: some key figures. Social Psychiatry and Psychiatric Epidemiology 2021;56:109-117.

https://doi.org/10.1007/s00127-020-01909-6

19. Chow WS, Priebe S. How has the extent of institutional mental healthcare changed in Western Europe? Analysis of data since 1990. BMJ Open 2016;6(4):e 010188.

https://doi.org/10.1136/bmjopen-2015-010188

20. Traub H-J, Tomlin J, Weithmann G, Flammer E, Völlm B. Court sentences to forensic-psychiatric treatment and imprisonment in Germany: Types of crimes and changes from 1995 to 2009. International Journal of Law and Psychiatry 2020;71.

https://doi.org/10.1016/j.ijlp.2020.101577

21. Jansman-Hart EM, Seto MC, Crocker AG, Nicholls TL, Côté G. International Trends in Demand for Forensic Mental Health Services. International Journal of Forensic Mental Health 2011;10, 326-336. https://doi.org/10.1080/14999013.2011.625591

22. Marquant T, Torres-Gonzalez F. Deinstitutionalization Versus Transinstitutionalization. in Forensic Psychiatry and Psychology in Europe. Springer International Publishing 2018:293-304. https://doi.org/10.1007/978-3-319-74664-7_19 
23. Chow WS, Ajaz A, Priebe S. What drives changes in institutionalised mental health care? A qualitative study of the perspectives of professional experts. Social Psychiatry and Psychiatric Epidemiology 2019;54:737-744. https://doi.org/10.1007/s00127-018-1634-7

24. Howitt S, Thomson L. Teaching Forensic Psychiatry and Psychology in Europe. in Forensic Psychiatry and Psychology in Europe. Springer International Publishing 2018:183-197. https://doi.org/10.1007/978-3-319-74664-7_12

25. How to become a psychiatrist. RCPsych 2018:1-4

https://www.rcpsych.ac.uk/become-a-psychiatrist/choose-psychiatry/how-to-become-a-psychiatrist

26. Nedopil N, Taylor P. Specialist Training in Forensic Psychiatry in Europe. in Forensic Psychiatry and Psychology in Europe 199-209. Springer International Publishing 2018. https:// doi.org/10.1007/978-3-319-74664-7_13

27. Kröber HL, Müller-Isberner R, Nedopil N, Saß H. DGPPN - Zertifizierung "Forensische Psychiatrie." Der Nervenarzt 2001;72, 973-974. https://doi.org/10.1007/s001150170015

28. DGPPN Gesellschaft. DGPPN-Zertifikat "Forensische Psychiatrie". 2021. https://www.dgppn.de/mitglieder/zertifzierungen/ forensische-psychiatrie.html

29. Carabellese F, Felthous AR. Closing Italian Forensic Psychiatry Hospitals in Favor of Treating Insanity Acquittees in the Community. Behavioral sciences \& the law 2016;34:444-459. https://doi.org/10.1002/bsl.2234

30. Catanesi R, Mandarelli G, Ferracuti S, Valerio A, Carabellese F. The new Italian residential forensic psychiatric system (REMS). a one-year population study. Rassegna Italiana di Criminologia 2019;13: 7-23.

31. Vorstenbosch E, Castelletti L. Exploring Needs and Quality of Life of Forensic Psychiatric Inpatients in the Reformed Italian System, Implications for Care and Safety. Frontiers in Psychiatry 2020;11:258.

https://doi.org/10.3389/fpsyt.2020.00258
32. Mead S, Hilton D, Curtis, L. Peer support: A theoretical perspective. Psychiatric Rehabilitation Journal 2001;25:134-141. https://doi.org/10.1037/h0095032

33. Repper J, et al. Briefing: Peer Support Workers: Theory and Practice. Centre for mental health.Org Uk 2013:1-16.

34. Walde P, Tomlin J, Völlm B. Peer Support Workers in Inpatient (Forensic) Mental Health Settings. in 29th European Congress of Psychiatry. EPA Virtual 2021.

\section{TEISMO PSICHIATRIJOS SITUACIJA EUROPOJE: BENDRASIS TEISINIS PAVELDAS IR ŠIUOLAIKINE் APŽVALGA \\ J. Tomlin, B. Völlm}

Raktažodžiai: Europa, teismo psichiatrija, sveikatos priežiūros sistema, teisinè bazè.

Santrauka

Šiame straipsnyje apžvelgiamos kai kurios pagrindinès teismo psichiatrijos sistemų ypatybės visoje Europoje. Teismo psichiatrijos sistemos bendras tikslas yra padèti reabilituoti žmones, kuriems diagnozuotas psichikos sutrikimas ir sumažinti pakartotinio nusikaltimo tikimybę ar žalos riziką. Šių tikslų ịvairiose šalyse siekiama skirtingais būdais. Siūlome, kad geriausios praktikos būtų išmoktos, stebint skirtingas patirtis. Šiame straipsnyje išskirti šeši aspektai: teisinès tradicijos Europoje, baudžiamosios atsakomybès samprata, pacientų keliai per teismo ekspertines sistemas, teismo psichiatrijos pacientų epidemiologiniai tyrimai, teismo psichiatrijos mokymo programos ir naujausi šios srities pasiekimai visoje Europoje. Skaitytojai turètų apmąstyti šias temas, atsižvelgdami i savo šali ir i tai, kaip jos skiriasi ar sutampa kitose šiame straipsnyje aprašytose šalyse.

Adresas susirašinèti: t.jack@greenwich.ac.uk

Gauta 2021-09-27 